\title{
Microbiological Quality, Shelf Life and Fermentation Activity of Active Dried Yeast ${ }^{1)}$
}

\author{
Estelle Simpson \& R.P. Tracey \\ Viticultural and Oenological Research Institute, Private Bag X5026, 7600 Stellenbosch, Republic of South Africa. \\ Submitted for publication: March 1986 \\ Accepted for publication: June 1986 \\ Keywords: Quality, shelf life, dried yeast
}

\begin{abstract}
The microbiological quality and shelf life of 10 active dried yeast preparations were determined. The dried yeasts were tested for total microbial count, total yeast count, total wild yeast count, total bacterial count, spore forming bacteria, Enterobacteriaceae and lactic acid bacteria. For the shelf life test, the yeasts were stored at $0^{\circ} \mathrm{C}, 4^{\circ} \mathrm{C}, 15^{\circ} \mathrm{C}$ and $25^{\circ} \mathrm{C}$ for six months and tested at monthly intervals for total viable yeast count and total bacterial count. After six months storage fermentations were carried out in Colombar must and the wines subsequently analysed. All dried yeasts complied with the International Wine Office (O.I.V.) guideline of $1 \times 10^{9}$ viable yeasts per gram dried yeast, whilst only some preparations complied with the guideline for total bacterial count of $1 \times 10^{5}$ bacteria per gram dried yeast. Results of the shelf life test showed optimum storage temperature to be $4^{\circ} \mathrm{C}$.
\end{abstract}

Cuinier \& Lacoste (1980) stated that the use of active dried yeast preparations (ADYP) presents the following advantages when compared to wines having undergone spontaneous fermentation: decrease in the lag phase, better completion of alcoholic fermentation, less acetaldehyde formed in certain wines and the absence of organoleptic differences.

The use of ADYP, especially in countries such as South Africa and Australia has, to a large extent, replaced spontaneous fermentations (Rankine, 1978). While various authors (Bauer \& Klein Henz, 1978; Rankine, 1978; Cuinier \& Lacoste, 1980; Bidan \& Maugenet, 1981) noted that wines prepared with ADYP did not differ from wines inoculated with liquid starters and spontaneous fermentations. On the other hand, Gaia \& Gandini (1983) found that wines inoculated with ADYP were superior to spontaneously fermented wines

Radler (1978) proposed the following criteria for ADYP quality: the total number of yeasts, the viability, the level of contaminating micro-organisms, indigenous yeasts, moulds, bacteria, lactic acid bacteria, the presence of additives and the date of production. Present guide lines of the International Wine Office (O.I.V.) in Paris, France, stipulate a minimum of $1 \times 10^{9}$ viable yeasts per gram ADYP and a maximum of $1 \times 10^{5}$ bacteria per gram ADYP (Anon., 1981). It is clear that the existing guidelines for the quality of ADYP are insufficient.

ADYP have a shelf life of one to three months when exposed to air or as long as one year when packed under nitrogen or vacuum (Chen, Cooper \& Gutmanis, 1966; Reed \& Chen, 1978). Packaging under nitrogen or vacuum does, however, increase the cost of ADYP. They further note that shelf life, even with different packaging, is dependent on storage temperature.

The purpose of this study was to determine the microbiological quality of ADYP, especially wine yeasts, from different manufacturers with a view to possibly establishing guidelines for ADYP quality. The effect of storage temperature on cell viability and fermentation ability was also examined.

\section{MATERIALS AND METHODS}

\section{Yeast strains:}

All ADYP included in this study were Saccharomyces cerevisiae strains. Six locally produced ADYP viz. WE 14, WE 372 (batches 1 and 2), WE 500 (batches 1 and 2) and a bakers' yeast strain 342, were obtained directly from the producer. Hefix $1000, \mathrm{~V}-1116$, Siha-I and M-1107 are imported ADYP and were obtained from a local winery.

\section{Microbiological quality:}

The microbiological quality of each batch of ADYP was determined immediately after receipt. Tests and media used, were the following: total microbial count plate count agar (Oxoid); total viable yeasts - Yeast Morphology (YM) agar (Difco); total wild yeasts - Lysine medium (Oxoid); total bacterial count - plate count agar (Oxoid); spore forming bacteria - plate count agar (Oxoid); Enterobacteriaceae - violet red bile agar (Merck); lactic acid bacteria - MRS agar (Merck) and tomato juice agar (Difco). For the bacterial tests Actidione $(\mathrm{BDH})(0,1 \mathrm{~g} / l)$ was added to the media to suppress yeast growth. The $\mathrm{pH}$ of the medium used for yeast counts was lowered to $\mathrm{pH} 5,0$ to suppress bacterial growth and all determinations were done in triplicate.

Rehydration of the ADYP was carried out in physiological salt solution (PSS) in test tubes in a waterbath at $43^{\circ} \mathrm{C}$ for 30 minutes. Dilution series were made in PSS and plated out in triplicate.

The presence of spore forming organisms was determined by placing the rehydrated ADYP in a waterbath at $80^{\circ} \mathrm{C}$ for 10 minutes. Plates were incubated at $30^{\circ} \mathrm{C}$, except the violet red bile agar plates which were incubated at $37^{\circ} \mathrm{C}$. Plate counts were done after three days with the exception of the Lysine medium which was examined on days three and five and counted on day seven. The lactic acid bacterial counts were done after 
one week. Yeast and bacterial counts are expressed per gram ADYP.

\section{Shelf life:}

The shelf life of the different ADYP was determined by storing samples of each strain at $0^{\circ} \mathrm{C}, 4^{\circ} \mathrm{C}, 15^{\circ} \mathrm{C}$ and $25^{\circ} \mathrm{C}$ for six months and doing a total viable yeast count, a total bacterial count and, where necessary, a wild yeast count at monthly intervals.

The monthly counts were carried out as described under microbiological quality. Results were expressed as percentage viable cells with the original count as $100 \%$.

\section{Accelerated shelf life test:}

After receiving the ADYP, an accelerated shelf life test was carried out by placing samples of the ADYP in air tight containers at $45^{\circ} \mathrm{C}$ for 28 days. Dilution plate counts for viable yeast cells were made at regular intervals for up to 28 days on YM agar. Results were expressed as percentage surviving cells taking the cell count of day 0 as $100 \%$.

\section{Fermentation activity:}

Fermentation activities were determined on all the samples of ADYP stored at the various temperatures. One gram dried yeast was rehydrated in $10 \mathrm{~m} l$ sterilised water and $1,5 \mathrm{ml}$ of this suspension was used to inoculate triplicate lots of $500 \mathrm{~m} l$ Colombar must. The must had a sugar content of $160 \mathrm{~g} / l$, a total acidity of $5,4 \mathrm{mg} / l$, a $\mathrm{pH}$ of 3,59 , a total $\mathrm{SO}_{2}$ content of $29 \mathrm{mg} / l$ and a free $\mathrm{SO}_{2}$ content of $5 \mathrm{mg} / l$. The fermentation progress at $15^{\circ} \mathrm{C}$ was followed by determining $\mathrm{CO}_{2}$ loss through regular weighing. After 21 days the fermentations were stopped and the wines were analysed for alcohol, sugar, volatile acidity, total acidity and $\mathrm{pH}$, using standard Viticultural and Oenological Research Institute (V.O.R.I.) methods.

\section{RESULTS AND DISCUSSION}

\section{Microbiological quality:}

Results of the microbiological tests carried out on the ADYP are presented in Table 1. The total microbial count varied from $8,2 \times 10^{9}$ for WE 14 to $5,9 \times 10^{10}$ for WE 372 (batch 2) and the total viable yeast counts varied from $1,3 \times 10^{9}$ (Hefix 1000) to $6,1 \times 10^{10}$ for WE 372 (batch 2). All the ADYP included in this study therefore complied with the guideline of $1 \times 10^{9}$ viable yeast cells/g ADYP set by the O.I.V. (Anon., 1981). Bidan \& Maugenet (1981) noted that a total of 38 ADYP, studied by various authors, were found to have viable yeast counts varying from $1 \times 10^{9}$ to $5 \times 10^{10}$. Results obtained in this study confirm these findings. The present guideline for a total viable yeast count of $1 \times 10^{9} / \mathrm{g}$ ADYP as laid down by the O.I.V., is regarded as a realistic figure and should be accepted.

Microbial counts per gram active dried yeast preparation (ADYP)

\begin{tabular}{|c|c|c|c|c|c|c|c|c|c|c|}
\hline \multirow[b]{2}{*}{ Microbial Tests } & \multicolumn{10}{|c|}{ ADYP } \\
\hline & $\begin{array}{l}\text { WE } 372 \\
\text { Batch } 1\end{array}$ & $\begin{array}{l}\text { WE } 372 \\
\text { Batch } 2\end{array}$ & WE 14 & $\begin{array}{l}\text { WE } 500 \\
\text { Batch } 1\end{array}$ & $\begin{array}{l}\text { WE } 500 \\
\text { Barch } 2\end{array}$ & $\begin{array}{c}\text { Bakers' } \\
\text { Yeast }\end{array}$ & $\begin{array}{c}\text { Hefix } \\
1000\end{array}$ & V-1116 & Siha-I & M-1107 \\
\hline Total microbial count & $2,3 \times 10^{10}$ & $5,9 \times 10^{10}$ & $8,2 \times 10^{9}$ & $1,1 \times 10^{10}$ & $1,2 \times 10^{10}$ & $1,6 \times 10^{10}$ & $3,6 \times 10^{10}$ & $4,4 \times 10^{10}$ & $2,1 \times 10^{10}$ & $1,3 \times 10^{10}$ \\
\hline Total yeast count & $2,8 \times 10^{10}$ & $6,1 \times 10^{10}$ & $8,0 \times 10^{10}$ & $1,2 \times 10^{10}$ & $1,3 \times 10^{10}$ & $1,6 \times 10^{10}$ & $1,3 \times 10^{9}$ & $2,4 \times 10^{10}$ & $2,5 \times 10^{10}$ & $2,0 \times 10^{9}$ \\
\hline Wild yeast count & 0 & $1,0 \times 10^{2}$ & 0 & $6,6 \times 10^{6}$ & $8,5 \times 10^{3}$ & $8,5 \times 10^{6}$ & $2,0 \times 10^{2}$ & $4,2 \times 10^{+}$ & 0 & 0 \\
\hline Total bacterial count & $9,0 \times 10^{4}$ & $3,1 \times 10^{6}$ & $1,2 \times 10^{5}$ & $4,7 \times 10^{6}$ & $4,1 \times 10^{7}$ & $4,4 \times 10^{7}$ & $4,4 \times 10^{8}$ & $2,5 \times 10^{5}$ & $1,0 \times 10^{4}$ & $1,9 \times 10^{5}$ \\
\hline Spore forming bacteria & $3,7 \times 10^{2}$ & $4,0 \times 10^{2}$ & $6,7 \times 10^{2}$ & $1,3 \times 10^{2}$ & $4,8 \times 10^{2}$ & $1,0 \times 10^{2}$ & $2,7 \times 10^{2}$ & $6,0 \times 10^{2}$ & 0 & $8,0 \times 10^{2}$ \\
\hline Lactic acid bacteria & $10 \times 10^{3}$ & $27 \times 10^{6}$ & $10 \times 10^{5}$ & & & $71 \times 10^{7}$ & & & & \\
\hline $\begin{array}{l}\text { (MRS agar) } \\
\text { Lactic acid bacteria }\end{array}$ & $1,9 \times 10^{3}$ & $3,2 \times 10^{6}$ & $1,0 \times 10^{5}$ & $3,0 \times 10^{6}$ & $x 10^{6}$ & $7,1 \times 10^{7}$ & $3,8 \times 10^{8}$ & $1,8 \times 10^{5}$ & $2,0 \times 10^{4}$ & $8,0 \times 10^{4}$ \\
\hline (Tomato juice agar) & $4,0 \times 10^{4}$ & $2,8 \times 10^{6}$ & $8,0 \times 10^{4}$ & $5,0 \times 10^{6}$ & $1,1 \times 10^{6}$ & $1,4 \times 10^{8}$ & $4,5 \times 10^{8}$ & $1,9 \times 10^{5}$ & $6,0 \times 10^{3}$ & $3,0 \times 10^{4}$ \\
\hline
\end{tabular}

Large variation was found in the wild yeast counts. Four ADYP were found to contain no wild yeasts, whilst the wild yeast counts for the remaining ADYP varied from $1,0 \times 10^{2}$ to $8,5 \times 10^{6}$. At present no guideline has been set by the O.I.V. for wild yeast counts in ADYP. It was commonly accepted that wild yeasts, especially of the genera Kloeckera, Hansensiaspora, Candida, Pichia and sometimes Hansenula, grow during the early stages of must fermentation but eventually die off (Fleet, Lafon-Lafourcade \& Ribéreau-Gayon, 1984; Lafon-Lafourcade \& Ribéreau-Gayon, 1984). Benda (1981) and Fleet et al. (1984) state that these genera may have important effects on wine flavor. However, Heard \& Fleet (1985) have shown that certain wild yeasts notably Kloeckera apiculata, Candida stellata and $C$. pulcherrima could contribute to wine fermentation. Care should be taken in using ADYP with too high a wild yeast count since Sacch. cerevisiae ADYP do not suppress the development of all natural yeasts during wine fermentation (Heard \& Fleet, 1985).
A maximum of $1 \times 10^{3}$ wild yeasts/g ADYP should be an acceptable guideline.

The total bacterial counts varied between ADYP with Siha-I containing the least bacteria $\left(1 \times 10^{4}\right)$, whilst Hefix 1000 had the highest total bacterial count $(4,4 \mathrm{x}$ $10^{8}$ ). The high count for Hefix 1000 can possibly be ascribed to the high number of lactic acid bacteria (see later). Siha-I was the only ADYP that did not contain any spore forming bacteria, whilst all the other preparations contained relatively low amounts of spore forming bacteria (between $1 \times 10^{2}$ and $8 \times 10^{2}$ ). Only WE 372 (batch 1) and WE 14 ADYP did not contain any Enterobacteriaceae whilst the concentration in the other ADYP studied, varied from $1,3 \times 10^{2}$ for M-1107 to $7,1 \times 10^{5}$ for WE 500 (batch 2) (Table 1). Benda (1984) found that even large numbers $\left(10^{7}\right.$ cells per $\left.\mathrm{m} l\right)$ of coliform did not survive longer than 48 hours in the wines that were tested. It should however be noted that the $\mathrm{pH}$ of wines studied by Benda (1984) was lower than 3,6 and the free $\mathrm{SO}_{2}$ concentration higher than 
$33 \mathrm{mg} / \mathrm{l}$. It is possible that Enterobacteriaceae will survive for longer periods, should these conditions change, expecially where the wine $\mathrm{pH}$ is notably higher (eg. $\mathrm{pH}$ 4).

O.I.V. guidelines for ADYP state that the bacterial counts should not exceed $1 \times 10^{5}$ bacteria/g ADYP and that the test be carried out on MRS agar which is a selective medium for Lactobacilli (Man, Rogosa \& Sharp, 1960). This could, however, lead to misinterpretation of the total bacterial count for the following reasons:

1. MRS agar is a selective medium for lactic acid bacteria, therefore other organisms present will not easily be detected;

2. and organisms of the species Leuconostoc oenos have a specific requirement for a tomato juice growth factor (Garvie \& Mabbitt, 1967) and will therefore not grow on MRS agar.

This study has shown that on average a higher recovery of lactic acid bacteria was obtained on tomato juice agar than on MRS agar (Table 1). The differences between the individual counts on the tomato juice agar and MRS agar can be ascribed to the differences in the lactic acid bacteria populations of the various ADYP. Furthermore, the total bacterial count was either of the same order or higher than the counts for lactic acid bacteria, with the exception of the bakers' yeast. It is therefore recommended that both a total bacterial count on a medium such as plate count agar and a lactic acid bacteria count on tomato juice agar be carried out on ADYP.

Only four of the ADYP tested (WE 372 (batch 1), WE 14, Siha-I and M-1107) complied with the O.I.V. guidelines for bacterial counts, whilst the lactic acid bacteria counts for the other ADYP were notably higher, up to $4,5 \times 10^{8}$. Radler, Dietrich \& Schönig (1985) found that the six ADYP studied by them, contained up to $2 \times 10^{7}$ bacteria. Tromp \& Strydom (1980), using tomato juice agar, found that the lactic acid bacteria count for six ADYP varied from $1 \times 10^{4}$ to $1 \times 10^{7}$. However, the present work has shown that the counts on the same medium for the ADYP studied varied from $6 \times 10^{3}$ to $4,5 \times 10^{8}$ (Table 1 ). A total bacterial count of $5 \times 10^{6} / \mathrm{g}$ ADYP and a lactic acid bacteria count of $1 \times 10^{6} / \mathrm{g}$ ADYP should be the accepted norms for these tests.

\section{Shelf life:}

The percentage surviving yeast cells after six months at the various storage temperatures is presented in Table 2. Of the two batches of strain WE 372 tested, batch 1 had a much better shelf life than batch 2 .

Batch 1 of this strain showed a better shelf life at $0^{\circ} \mathrm{C}$, $4^{\circ} \mathrm{C}$ and $15^{\circ} \mathrm{C}$ (above $81 \%$ ), than batch 2 which had only $62 \%$ viable yeasts after six months at $0^{\circ} \mathrm{C}$ and markedly lower counts at the other temperatures. This shows that shelf life is not a characteristic of a specific yeast strain, but depends on manufacturing conditions.

Over the six months period the viable yeast counts for strain WE 14 were $66 \%$ and $69 \%$ at $0^{\circ} \mathrm{C}$ and $4^{\circ} \mathrm{C}$ respectively, which were markedly higher than at the higher storage temperatures. Both batches of WE 500 showed tendencies similar to WE 14 at $0^{\circ} \mathrm{C}$ and $4^{\circ} \mathrm{C}$ whilst at $25^{\circ} \mathrm{C}$ the viable yeast count for WE 500 was markedly lower. The shelf life of the bakers' yeast strain was comparable to WE 500 although the keeping

\section{TABLE 2}

Percentage survival of total viable yeasts of active dried yeast preparations stored at various temperatures for six months. (Values in Table 1 taken as $100 \%$ )

\begin{tabular}{|c|c|c|c|c|c|}
\hline \multirow{2}{*}{\multicolumn{2}{|c|}{ Yeast strain }} & \multicolumn{4}{|c|}{ Survival (\%) } \\
\hline & & \multirow{2}{*}{$\frac{0^{\circ} \mathrm{C}}{84,0}$} & \multirow{2}{*}{$\frac{4^{\circ} \mathrm{C}}{100,0}$} & \multirow{2}{*}{$\begin{array}{l}15^{\circ} \mathrm{C} \\
81,0\end{array}$} & \multirow{2}{*}{$\frac{25^{\circ} \mathrm{C}}{34,0}$} \\
\hline WE 372 & (Batch 1) & & & & \\
\hline & (Batch 2) & 62,0 & 33,0 & 31,0 & 15,0 \\
\hline WE 14 & & 66,0 & 69,0 & 45,0 & 23,0 \\
\hline \multirow[t]{2}{*}{ WE 500} & (Batch 1) & 74,0 & 63,0 & 28,0 & 0,1 \\
\hline & (Batch 2) & 55,0 & 61,0 & 47,0 & 4,0 \\
\hline \multicolumn{2}{|c|}{ Bakers' yeast 343} & 70,0 & 71,0 & 50,0 & 2,0 \\
\hline \multicolumn{2}{|c|}{ Hefix 1000} & 40,0 & 35,0 & 1,0 & 3,0 \\
\hline \multicolumn{2}{|c|}{ V-1116 } & 96,0 & 98,0 & 96,0 & 63,0 \\
\hline \multicolumn{2}{|l|}{ Siha-I } & 60,0 & 56,0 & 50,0 & 12,0 \\
\hline \multicolumn{2}{|l|}{ M-1107 } & 72,0 & 70,0 & 62,0 & 55,0 \\
\hline
\end{tabular}

quality was better at $0^{\circ} \mathrm{C}$ and $4^{\circ} \mathrm{C}$. Of all the strains tested Hefix 1000 had the poorest shelf life with only $40 \%$ and $35 \%$ survival at $0^{\circ} \mathrm{C}$ and $4^{\circ} \mathrm{C}$ respectively after six months.

Strain V-1116 had the best keeping quality at all temperatures of all strains studied, especially at $15^{\circ} \mathrm{C}$ and lower. The shelf life at $0^{\circ} \mathrm{C}, 4^{\circ} \mathrm{C}$ and $15^{\circ} \mathrm{C}$ of Siha-I varied from 50 to $60 \%$ whilst only $12 \%$ surviving yeasts were counted at $25^{\circ} \mathrm{C}$ after six months. With the exception of $25^{\circ} \mathrm{C}, \mathrm{M}-1107$ yielded results similar to those of the bakers' yeast strain. Tromp \& Strydom (1980) recommended that storage should be below $20^{\circ} \mathrm{C}$. Results of this study indicate that storage should preferably be carried out at $4^{\circ} \mathrm{C}$. Little variation was obtained between $0^{\circ} \mathrm{C}$ and $4^{\circ} \mathrm{C}$.

\section{Accelerated shelf life test:}

An accelerated shelf life test was previously done at the V.O.R.I. on the ADYP at $45^{\circ} \mathrm{C}$ for 21 days. This test was included in this study to determine whether there is any relationship between the accelerated shelf life test and the keeping quality at the different storage temperatures. However, no relationship was found at $0^{\circ} \mathrm{C}, 4^{\circ} \mathrm{C}$ and $15^{\circ} \mathrm{C}$, whilst in some cases similar results were obtained with the accelerated shelf life test and storage at $25^{\circ} \mathrm{C}$. This fact is substantiated by, for example, strain WE 372 (batch 1) which had, on average, a $88 \%$ survival after six months at $0^{\circ} \mathrm{C}, 4^{\circ} \mathrm{C}$ and $15^{\circ} \mathrm{C}$, whilst with the accelerated shelf life test only $9 \%$ viable yeasts were counted after 28 days. Although there was only a slight loss of viability for strain $\mathrm{V}-1116$ at $0^{\circ} \mathrm{C}$, $4^{\circ} \mathrm{C}$ and $15^{\circ} \mathrm{C}$ after six months, the accelerated shelf life test showed only $25 \%$ viability after five days and $2,5 \%$ after 28 days. The accelerated shelf life test, as included in this study, is therefore not effective for testing the shelf life of ADYP and a substitute test should be found.

\section{Fermentation activity:}

Yeast stored at higher temperatures had longer lag phases and slower fermentation rates than those stored at lower temperatures (Fig. 1). The longer lag phase and slower fermentation rate can be ascribed to the loss of viability at the higher temperatures. However, three ADYP (WE 372 (batch 1), WE 500 (batch 2) and V-1116) stored at $15^{\circ} \mathrm{C}$ displayed similar fermentation curves to those stored at $0^{\circ} \mathrm{C}$ and $4^{\circ} \mathrm{C}$. Strain V-1116 which had the best shelf life was the only strain where the fermentation activity of the ADYP stored at $25^{\circ} \mathrm{C}$ was comparable with the results obtained at the other tempera- 


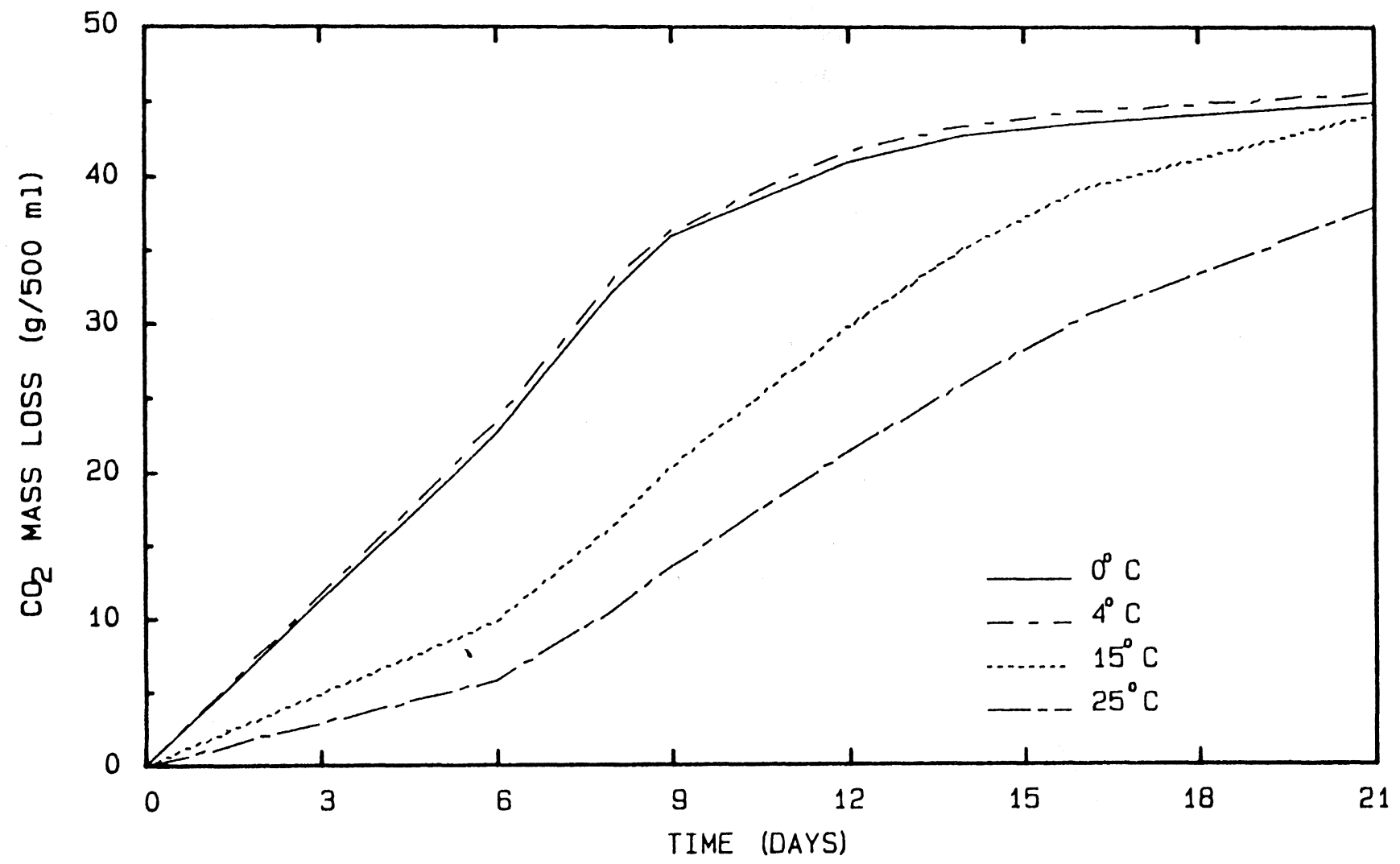

FIG. 1

Fermentation activity of WE 500 in Colombar must after storage for six months at different temperatures.

tures. Previously it has been shown that reserve carbohydrates (trehalose and glycogen) effect the shelf life and fermentation activity of ADYP (Bocharova, Chernysh \& Ozerova, 1973). It is possible that differences in reserve carbohydrates may be one of the reasons for the above differences.

\section{Wine analyses:}

Of all the analyses carried out on the wines, only the $\mathrm{pH}$ remained constant (data not shown). From Table 3 it is clear that the higher the ADYP storage temperature, the higher the residual sugar concentration and thus the lower the alcohol concentration. This is true for all the ADYP with the notable exceptions of WE 372 (batch 2) and V-1116. The volatile acidity increases with an increase in storage temperature, possibly due to the longer lag phases and slower fermentation rates of these fermentations. This is a common phenomenon which has not yet been explained.

As was the case with the viable yeast cell counts after storage at the different temperatures for six months, strains WE 372 (batch 2) and V-1116 did not show any notable difference in the analyses of the wines. Both batches of WE 500 and strain M-1107 showed large differences in shelf life at the different storage temperatures. Likewise the analyses of the wines made from these strains showed large differences. Total acidity of the wines showed similar tendencies to the volatile acidity.

\section{CONCLUSIONS}

On comparison of the microbiological quality of the ADYP, it was noted that the total microbial count,

TABLE 3

Sugar concentration and volatile acidity of Colombar wine after fermentation for 21 days with active dried yeast preparations stored at various temperatures for six months.

\begin{tabular}{|c|c|c|c|c|c|c|c|c|}
\hline \multirow[b]{2}{*}{ Yeast strain } & \multicolumn{4}{|c|}{ Sugar $(\mathrm{g} / l)$} & \multicolumn{4}{|c|}{ Volatile acid $(\mathrm{mg} / \mathrm{l})$} \\
\hline & $0^{\circ} \mathrm{C}$ & $4^{\circ} \mathrm{C}$ & $15^{\circ} \mathrm{C}$ & $25^{\circ} \mathrm{C}$ & $0^{\circ} \mathrm{C}$ & $4^{\circ} \mathrm{C}$ & $15^{\circ} \mathrm{C}$ & $25^{\circ} \mathrm{C}$ \\
\hline WE 372 (Batch 1) & 11,9 & 12,4 & $\begin{array}{r}11,1 \\
5,3\end{array}$ & 11,5 & 0,51 & 0,57 & 0,72 & 0,76 \\
\hline WE 14 & 20,5 & $\begin{array}{r}11,2 \\
3,8\end{array}$ & 5,3 & 10,0 & $\begin{array}{l}0,54 \\
0,58\end{array}$ & 0,44 & 0,56 & 0,64 \\
\hline 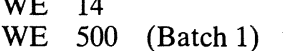 & $\begin{array}{l}4,0 \\
6,0\end{array}$ & $\begin{array}{l}5,0 \\
5,0\end{array}$ & $\begin{array}{r}5,7 \\
13,4\end{array}$ & $\begin{array}{l}15,4 \\
35,1\end{array}$ & $\begin{array}{r}0,58 \\
0,55\end{array}$ & 0,42 & 0,46 & 0,64 \\
\hline (Batch 2) & $\begin{array}{l}3,0 \\
3,6\end{array}$ & 4,6 & $\begin{array}{r}13,4 \\
4,7\end{array}$ & $\begin{array}{l}35,1 \\
29,8\end{array}$ & $\begin{array}{l}0,55 \\
0,63\end{array}$ & $\begin{array}{l}0,50 \\
0,59\end{array}$ & $\begin{array}{l}1,09 \\
0,73\end{array}$ & 1,18 \\
\hline Bakers' yeast 342 & 22,9 & 23,8 & 23,9 & 54,1 & 0,42 & 0,40 & 0,56 & 0,69 \\
\hline Hefix 1000 & 34,1 & 31,7 & 57,6 & 63,5 & 0,43 & 0,51 & 0,72 & 0,72 \\
\hline V-1116 & 3,1 & 3,9 & 2,5 & 2,9 & 0,42 & 0,40 & 0,42 & 0,47 \\
\hline Siha-I & 7,0 & 7,7 & 9,9 & 12,0 & 0,40 & 0,42 & 0,43 & 0,57 \\
\hline M-1107 & 14,8 & 14,2 & 18,4 & 148,3 & 0,42 & 0,44 & 0,55 & 1,34 \\
\hline
\end{tabular}


total yeast count, total bacterial count and total spore forming bacteria were of the same order, whilst varying concentrations of wild yeasts, Enterobacteriaceae and lactic acid bacteria were found. The six locally produced ADYP yielded similar results for the microbiological tests with the exception of the bakers' yeast strain which contained more lactic acid bacteria and less spore forming bacteria than the other ADYP.

It is recommended that the present guideline for a total viable yeast count of $1 \times 10^{9} / \mathrm{g}$ ADYP as laid down by the O.I.V. be accepted. However, a total bacterial count of $5 \times 10^{6} / \mathrm{g}$ ADYP and a lactic acid bacteria count of $1 \times 10^{6} / \mathrm{g}$ ADYP should be the accepted norms for these tests. A maximum of $1 \times 10^{3}$ wild yeasts/g ADYP should also be acceptable.

Results clearly indicate that low storage temperatures are essential for the survival of ADYP even for short periods of time. Room temperature $\left(25^{\circ} \mathrm{C}\right)$ is clearly not desirable. It must be emphasised that ADYP should be treated with care and stored at low temperatures $\left(0^{\circ} \mathrm{C}\right.$ to $\left.4^{\circ} \mathrm{C}\right)$ even for short periods of time.
ANONYMOUS, 1981. Active dried yeasts in oenology. Office international de la vigne et du vin. Document no. 1006, Paris.

BAUER, K. \& KLEIN HENZ, J., 1978. 'Technologische Kenngrössen van Trockenhefen. Wein Wiss. 33, 188-199.

BENDA, I., 1981. Wine and brandy. p. 293-402. In: Prescott and Dunn's industrial microbiology. G. Reed, Ed. AVI Technical Books Inc. Westport, Conn.

BENDA, I., 1984. Zum vorkommen von Koli- und Koliformen bakterien in wein. Mitt. Klosterneuburg 34, 249-251.

BIDAN, P. \& MAUGENET, J., 1981. Information réciente sur l'emploi des levures séches actives. Bull. O.I.V. 54, 241-254.

BOCHAROVA, N.N., CHERNYSH V.G. \& OZEROVA, V.P., 1973. Metabolism of reserve carbohydrates in dividing and resting yeast cells. Mikrobiologiya 42, 800-805.

CHEN, S.L., COOPER, E.J. \& GUTMANIS, F., 1966. Active dry yeast: Protection against oxidative deterioration during storage. Food Tech. 20, 79-83.

CUINIER, C. \& LACOSTE, J., 1980. Essai d'utilisation de levures sèches actives en Touraine. Controle de l'efficacite du levurage. Conn, Vigne Vin 14, 53-64.

FLEET, G.H., LAFON-LAFOURCADE, S. \& RIBÉREAUGAYON, P., 1984. Evolution of yeasts and lactic acid bacteria during fermentation and storage of Bordeaux wines. Appl. Environ. Microbiol. 48, 1034-1038.

GAIA, P. \& GANDINI, A., 1983. Verifica dele caratteristiche enologiche di alcuni allestimenti commerciali di lieviti secchi attivi. Accad. Ital. Della Vite Vino 35, 243-252.
GARVIE, E.E. \& MABBITT, L.A., 1967. Stimulation of the growth of Leuconostoc oenos by tomato juice. Arch. Mikrobiol. $55,398-407$.

HEARD, M.H. \& FLEET, G.H., 1985. Growth of natural yeast flora during fermentation of inoculated wines. Appl. Environ. Microbiol. 50, 727-728.

LAFON-LAFOURCADE, S. \& RIBÉREAU-GAYON, P., 1984 Developments in the microbiology of wine production. p. 1-34. In: Progress in industrial microbiology, vol. 19: Modern applications of traditional biotechnologies. M.E. Bushell, ed. Elsevier Publishing Co., Oxford

MAN, J.C. DE., ROGOSA, M. \& SHARP, M.E., 1960. A medium for the cultivation of Lactobacilli. J. Appl. Bact. 23, 130-138.

OFFICE INTERNATIONAL DE LA VIGNE ET DU VIN, 1981. Active dried yeasts in Oenology. Paris: Document nr. 1006.

RADLER, F., 1978. Microbiologie du vin., Compte-rendu de la $13^{e}$ réunion de la sous-commission. Bull. O.I.V. 51, 805-827.

RADLER, F., DIETRICH, K. \& SCHÖNIG, I., 1985. Mikrobiologiese Prüfung von Trockenhefepräparaten für die Weinbereitung. Dt. Lebensmittelfhund. 81, 73-77.

RANKINE, B.C., 1978. Acquisitions récente dans la sélection et l'utilisation des souches de levures pures en oenologie. Ann. Technol. Agric. 27, 189-200.

REED, G. \& CHEN, S.L., 1978. Evaluating commercial active dry wine yeasts by fermentation activity. Am. J. Enol. Vitic. 29, 165-168.

TROMP, A. \& STRYDOM, M., 1980. Use of active dried wine yeast in the wine industry. Leaflet H17. Pretoria: Dept. of Agriculture. 